\title{
Television ja Twitterin risteyksessä
}

\author{
Sosiaalinen televisio vuorovaikutuksen \\ ja mediatapahtumaan osallistumisen välineenä
}

\author{
ELINA SALOMAA
}

\section{Väitöksenalkajaisesitelmä Jyväskylän yliopistossa 1. marraskuuta 2019}

Elämme keskellä mediamaailman murrosta. Teknologian kehittymisen myötä jokainen voi kuljettaa taskussaan laitetta, jonka kautta on mahdollista olla jatkuvasti saatavilla, yhteydessä muihin ja koko ajan tietoinen siitä, mitä maailmassa kullakin hetkellä on meneillään. Kasvava määrä erilaisia sosiaalisen median palveluita puolestaan tarjoaa alustan tuohon reaaliaikaiseen yhteydenpitoon sekä informaation välittämiseen ja jakamiseen. Kuka tahansa voi tuottaa sisältöä näille alustoille, mikä vaikuttaa väistämättä myös perinteisen median roolijakoon: siinä missä sanomalehti tai televisio välittivät aikanaan tietoa melko yksisuuntaisesti joukkoyleisölle, voi tuo yleisö nyt tehdä itsestään näkyvän ja kuuluvan. Sosiaalisen median kautta aiemmin passiivisiksi kuluttajiksi ja sohvaperunoiksi leimatut vastaanottajat voivat nyt reagoida välittömästi niihin mediasisältöihin, joita he lukevat, katsovat tai kuuntelevat.

Yleisön osallistuminen televisio- tai radio-ohjelmaan ei ole uusi ilmiö. Katsojat ja kuuntelijat ovat voineet osallistua lähetykseen vuosikymmenien ajan esimerkiksi soittamalla, kirjeitse tai tekstiviestillä (ks. Thornborrow 2015). 2010-luvulla osallistumistavat ovat kuitenkin osin muuttuneet, ja keskeisimmäksi osallistumisväyläksi on muotoutunut sosiaalinen media - aivan erityisesti Twitter (Atifi \& Marcoccia 2017: 3133). Puhelintaan television katselun ohessa selaava katsoja voikin varsin helposti liittyä televisio-ohjelmasta käytävään keskusteluun vain valitsemalla viestilleen sellaisen aihetunnisteen, joka linkittää tviitin osaksi tuon aihetunnisteen viestiketjua. Sosiaalisen median potentiaali ei ole jäänyt huomaamatta ohjelmantarjoajiltakaan, jotka kehittävät jatkuvasti uusia tapoja osallistaa katsojia lähetyksiinsä. Väitöstutkimukseni kohde, sosiaalinen televisio, on tästä yksi erinomainen esimerkki. Sosiaalisella televisiolla viitataan tavallisesti nykytelevisiolle tyypilliseen käytäntöön, jossa televisiotuottaja tarjoaa katsojille jaetun aihetunnisteen eli hashtagin. Aihetunniste muodos- 
taa keskustelun kiintopisteen ja ytimen, jonka ympärillä keskustelua ohjelmasta voidaan käydä sosiaalisen median alustoilla reaaliaikaisesti. Lisäksi sosiaalisen television perusperiaatteeseen kuuluu, että tällaiseen reaaliaikaiseen kommentointiin, livetviittaamiseen, houkutellaan näyttämällä joitakin katsojien viestejä televisioruudulla lähetyksen aikana. (Harrington 2014: 241-242; Atifi \& Marcoccia 2017: 32.)

Erityisen kiinnostavaa tällaisessa uudenlaisessa mediasekoituksessa, jossa perinteinen ja sosiaalinen media törmäävät toisiinsa, on se, että nämä mediat toimivat lähtökohtaisesti varsin erilaisilla toimintalogiikoilla. Perinteinen media edustaa yksisuuntaisuutta ja institutionaalisuutta, mikä tarkoittaa, että vain tarkoin valituilla henkilöillä on pääsy julkiseen vuorovaikutukseen. Sosiaalista mediaa puolestaan leimaavat rajaton osallistujamäärä ja suhteellisen tasavertaiset osallistumisoikeudet. (Landert 2017: 31.) Mitä sitten tapahtuu, kun nämä toimintalogiikat kohtaavat? Tähän medioiden risteykseen olen artikkelimuotoisessa väitöskirjassani pureutunut.

Tutkimuskohteenani on ollut yksi maailman suurimmista mediatapahtumista, jalkapallon MM-kisat. Twitteriä onkin hyödynnetty television katselun oheisnäyttämönä tavallisimmin juuri mediatapahtumien yhteydessä (Harrington 2014: 241). Suomalaiskatsojien Twitter-aktiivisuutta mitanneen SomeTV:n (2014) mukaan vuonna 2014 kymmenen kaikkien aikojen tviitatuimman ohjelman joukossa oli peräti kuusi mediatapahtumaa. Esimerkiksi eduskuntavaalit ja itsenäisyyspäivän vastaanotto ovat vuosi toisensa jälkeen innoittaneet suomalaiskatsojia jakamaan mielipiteitään. Katsotuimpia - ja nykyään myös tviitatuimpia - mediatapahtumia sekä meillä että maailmalla ovat kuitenkin toistuvasti erilaiset urheilulähetykset. Tästä todisteena voitaneen pitää sitä, että ympäri maailman lähetettiin yli 35,5 miljoonaa tviittiä Brasilian ja Saksan välisen surullisenkuuluisan välieräottelun aikana vuonna 2014 (Yle 2014). Näissä viesteissä katsojat ilmaisivat muun muassa tunteitaan, ja 140 merkkiin saatiin mahdutettua niin vahingoniloa, surua, hämmennystä kuin riemuakin.

Nähdäkseni Twitter sopii täydentämään tällaisia tapahtumia kolmesta syystä. Ensinnäkin mediaspektaakkelit perustuvat mukanaolon kokemukseen, ja tunnetta tapahtumien kulussa elämisestä voidaan vahvistaa reaaliaikaisilla ja nopeatempoisilla tviiteillä (Deller 2011: 222-223). Toiseksi Twitter on avoin ja julkinen alusta, jolla tviitit voivat levitä laajalle. Siten live-tviittaaminen mahdollistaa itseilmaisun ja oman katsomiskokemuksen esiintuomisen varsin vaivattomasti. (Page 2012: 183.) Kolmanneksi Twitterin kautta osallistujat voivat rakentaa vuorovaikutussuhteita paitsi muihin tviittaajiin, potentiaalisesti myös televisio-osallistujiin (Highfield 2014; Atifi \& Marcoccia 2017).

Aiempi sosiaalisen television tutkimus on osoittanut, että katsojat tviittaavat katselunsa ohessa muun muassa arvioidakseen ohjelmaa tai sen henkilöitä, jakaakseen informaatiota muille katsojille tai viihdyttääkseen aihetunnisteen ympärille kerääntynyttä tilapäisyhteisöä (esim. Selva 2016; Atifi \& Marcoccia 2017). Lisäksi on osoitettu, että katsojat suuntaavat viestejään jonkin verran myös suoraan televisiolle (Highfield 2014; Atifi \& Marcoccia 2017). Aiemmissa tutkimuksissa näitä tehtäviä on selvitetty pääosin kyselyiden, haastatteluiden tai sisällönanalyysin avulla. Lähestymistapani eroaa näistä tutkimuksista oleellisesti siinä, etten ole tarkastellut tviittejä pelkästään teksteinä vaan ennen kaikkea sosiaalisena toimintana. Seuraava esimerkki havainnollistaa lähestymistapaani. 
(1) Älkää näyttäkö itkeviä brasilialaislapsia! \#ylemmfutis

( 5 uudelleentviittausta, 1 tykkäys)

(Twitter 9.7.2014 00.29)

Esimerkissä 1 on nähtävissä, miten tviittaaja kytkee viestinsä televisiolähetykseen \#ylemmfutis-aihetunnisteen avulla. Ylen lähetyksessään tarjoaman tunnisteen kautta kieltomuotoinen käsky älkää näyttäkö itkeviä brasilialaislapsia ohjaa tviitin lukijaa tulkitsemaan viestiä suhteessa lähetykseen. Kun tviittiä tarkastellaan rinnan televisiokuvan (kuva 1) kanssa, voidaankin huomata, että kansainvälinen ohjaaja on poiminut televisiokuviin itkevän lapsen vain kaksi minuuttia ennen tviitin lähettämistä.

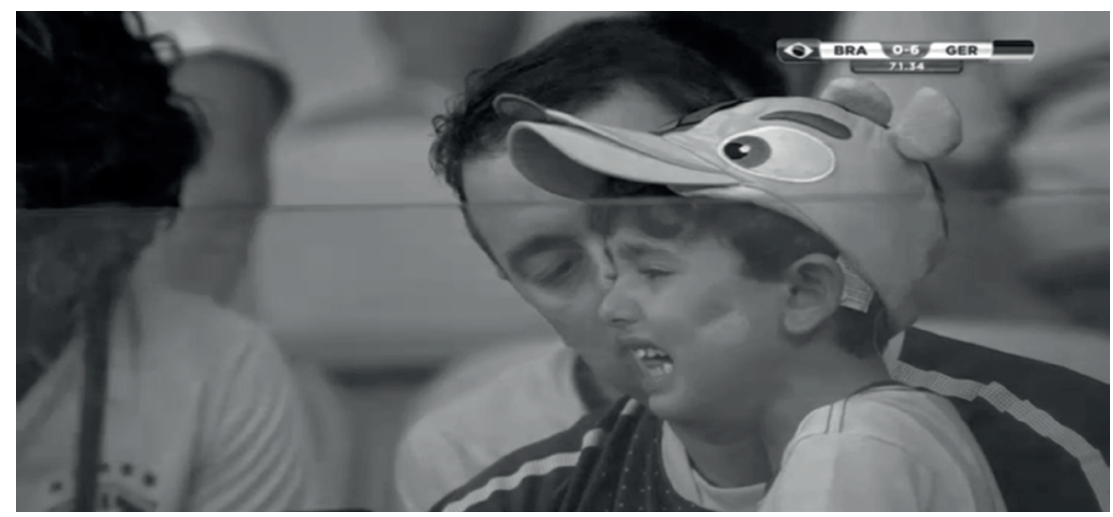

Kuva 1.

Ylen televisiokuvaa Brasilian ja Saksan välisestä ottelusta (Televisio 9.7.2014 00.27).

Tällä tavalla on osoitettavissa, että tviittaaja reagoi lähetykseen ja kytkee viestinsä siihen. Hän rakentaa lähetykseen toiminnallisen vuorovaikutussuhteen pyrkien käskyllään ohjaamaan siinä juuri nähtyä sopimatonta toimintaa. On kuitenkin huomattava, että tviitti ei kytkeydy pelkästään televisioon vaan myös osaksi Twitter-keskustelua, mikä tulee näkyviin siinä, millä tavoin tviittiin reagoidaan. Esimerkissä 1 tviitin saamat tykkäykset ja uudelleentviittaukset osoittavat, että muut tviittaajat ovat huomioineet tviitin ja ilmaisevat suhtautuvansa siihen enemmän tai vähemmän samanmielisesti (Meier, Elsweiler \& Wilson 2014: 352). Tästä näkökulmasta olennaista ei niinkään ole käskeminen vaan viestin sisältämä kannanotto: tviittaajat asettuvat ikään kuin yhdessä kritisoimaan itkevien lasten näyttämistä televisiolähetyksessä. Esimerkki osoittaa, että live-tviittaajat toimivat kaiken aikaa tietynlaisessa kaksoisroolissa televisiolähetyksen vastaanottajina ja sen kommentoijina.

Tästä syystä on nähdäkseni ollut aiheellista keskittyä pelkkien tviittisisältöjen sijaan ensisijaisesti siihen, mitä tviiteissä tehdään osana senhetkistä vuorovaikutustilannetta. Olenkin analyysissa tukeutunut sekä \#ylemmfutis-tviitteihin että siihen Ylen lähetykseen, josta tviittaajat kulloinkin keskustelevat. Tällä tavalla olen päässyt käsiksi siihen, miten viestit järjestyvät merkityksellisiksi kokonaisuuksiksi yhtäältä suhteessa toisiinsa, toisaalta suhteessa televisiolähetykseen. Vuorovaikutukseen painottuva näkökulmani on mahdollistanut tviittien tarkastelemisen monifunktioisena toimintana. 
Diskursiiviseen viitekehykseen pohjaten näen, että kieli rakentaa sosiaalista todellisuutta: kielen kautta voimme samanaikaisesti kuvata kohteita, rakentaa identiteettejä sekä luoda ja ylläpitää suhteita muihin (Fairclough 1995: 80). Voimme siis esimerkin tavoin samanaikaisesti käskeä yhtä osallistujaa toimimaan tilanteen vaatimalla tavalla, arvioida tämän toimintaa muille vuorovaikutustilanteen osallistujille ja rakentaa yhteisöllisyyttä tuon ryhmän kanssa.

Mielenkiintoiseksi tutkimusasetelman on tehnyt se, että osallistujat rakentavat kokemusta yhteisestä katselutilanteesta digitaalisesti. Jos vertaamme live-tviittaamista sellaiseen tilanteeseen, jossa lähetystä katsotaan fyysisesti samassa olohuoneessa, voimme huomata tilanteissa joitakin melko olennaisia eroja. Ensinnäkin sohvan jakavan ystävän kanssa keskustelu on todennäköisesti puhuttua, kun taas tviittaaminen on pääosin kirjoittamista. Tviitteihin ei ole mahdollista sijoittaa eleitä tai ilmeitä, kasvokkaisesta vuorovaikutuksesta puolestaan puuttuvat emojit ja linkit. (Giles, Stommel, Paulus, Lester \& Reed 2015: 48.) Toisin sanoen näissä tilanteissa osallistujilla on käytössään erilaisia resursseja, joilla he voivat rakentaa ja ylläpitää keskustelua. Toiseksi olohuonekeskustelu on varsin yksityinen keskustelutilanne, johon on pääsy vain sinne kutsutuilla henkilöillä. Twitter-keskustelu puolestaan on julkinen, eikä kommentoija voi täysin kontrolloida sitä, kuka tai kuinka moni viestiin vastaa (mas. 2015: 49). Nämä tekijät vaikuttavat ratkaisevalla tavalla siihen, miten osoitamme jotakin ympäristössä, millä tavalla siirrymme keskustelunaiheesta toiseen tai linkitämme puheenvuoromme vastaukseksi edelliseen. Tutkimuksellani olenkin osallistunut yhä ajankohtaisempaan keskusteluun siitä, miten vuorovaikutusta ja osallistumista rakennetaan ja ylläpidetään digitaalisissa ympäristöissä.

Sosiaalisen median on nähty demokratisoivan joukkoviestintää ja murtavan perinteisiä yleisön ja tuottajan rooleja (Chovanec \& Dynel 2015: 7; Atifi \& Marcoccia 2017). Tutkimukseni vahvistaa osin tätä näkemystä. Siinä missä televisiolla on aiemmin ollut valta asettaa katsojiaan tietynlaisiin rooleihin ja puhutella heitä esimerkiksi tietyn kansakunnan edustajina, voivat katsojat nyt itse asemoida itsensä sellaisiin rooleihin, joihin heillä ei aiemmin ole ollut julkista pääsyä. Tämä ei kuitenkaan automaattisesti tarkoita sitä, että television rooli muuttuisi dramaattisesti. Vaikka lineaarisen television kuolemaa on povattu jo pitkään (Enli \& Syvertsen 2016), tutkimukseni osoittaa television yhä keskeiseksi osaksi mediatapahtuman kokemista. Sosiaalinen televisio näyttääkin tehokkaalta työkalulta erityisesti ohjelmantarjoajalle, sillä sen avulla lukuisille alustoille pirstaloitunut tapahtuma voidaan keskittää jälleen televisioon. Jotta tviittaajat voivat osoittaa asiantuntemustaan ja faniuttaan tai viihdyttää muita tviittaajia tarkoituksenmukaisella tavalla, on heidän seurattava lähetystä intensiivisesti ja reagoitava televisiotapahtumiin mahdollisimman nopeasti.

Mediatutkija Nick Couldryn (2003: 97-99) mukaan televisio on pitkään toiminut sosiaalisen todellisuutemme ytimenä määräten, mikä milloinkin on yhteiskunnassamme merkityksellistä. Samalla se on määritellyt myös niitä ihmisiä, jotka pääsevät esiintymään julkisesti televisioyleisölle (mts. 47-48). Tämä television valta tuli havainnollistavalla tavalla näkyviin myös tutkimissani tviiteissä. Jalkapallon MMkisojen aikana tviittaajilla oli tapana onnitella televisioruudulla vilahtaneen tviitin kirjoittajaa lähetykseen pääsemisestä tai muulla tavoin osoittaa, että televisioon pääsemi- 
nen itsessään on jollakin tavalla ansiokasta. Tällainen käytäntö osoittaa, että televisio on säilyttänyt statuksensa televisiokatsojalle merkityksellisenä paikkana.

Väitöskirjassani olen tarttunut aiheeseen, jonka katson tarjoavan arvokasta ja ajankohtaista tietoa perinteisen ja sosiaalisen median kietoutumisesta yhteen ja erityisesti siitä, miten osallistujat ovat vuorovaikutuksessa keskenään medioiden solmukohdissa. Tutkimukseni tuloksia on mahdollista hyödyntää ja soveltaa erilaisissa konteksteissa. Mediatuottajille tutkimus tarjoaa kurkistuksen siihen, miten yleisö todellisuudessa käyttää hyväkseen mahdollisuutta osallistua mediasisältöön. Nykyään mediamaisemaa leimaavat erilaiset somekohut, jotka havainnollistavat hyvin, miten erilaiset puheenaiheet kiertävät nopeasti perinteisestä mediasta someen ja sieltä takaisin. Näissä kohuissa tulee usein näkyviin, miten osallistujien roolit toimittajana, yleisönä tai asiantuntijana rakoilevat mielenkiintoisella tavalla. Toisaalta tutkimukseni voi tarjota tarttumapintaa myös muihin digitaalisen osallistumisen ja vuorovaikutuksen konteksteihin. Osallistuva kansalainen on jo jonkin aikaa nähty monenlaisessa yhteiskunnallisessa toiminnassa ihanteena, jonka on toivottu toteutuvan juuri digitalisaation avulla. Esimerkiksi oppimistilanteissa, organisaatioissa tai kunnissa hyödynnetään jatkuvasti digitaalisia välineitä, joilla opiskelijoita, työntekijöitä tai kuntalaisia saataisiin osallistettua yhteiseen toimintaan.

Sosiaalinen media on muuttanut tapojamme vastaanottaa ja kuluttaa mediasisältöjä, mutta se ei toistaiseksi ole mediatapahtuman kohdalla horjuttanut television asemaa sosiaalisen todellisuutemme ytimessä. Nopeasti muuttuva mediamaisema muokkaa kuitenkin jatkuvasti yleisön osallistumisen tapoja. Nähdäkseni tällä hetkellä sosiaalinen televisio on haarautumassa kolmeen suuntaan. Ensiksikin livetviittaaminen on saanut reaaliaikaisten mediatapahtumien lisäksi vahvan jalansijan myös nauhoitettujen ohjelmien, esimerkiksi tosi-tv:n, katselun yhteydessä. Vaikka ohjelmat eivät tapahdu tässä ja nyt, katsojien jakama katselukokemus on yhteinen, ja siten se vahvistaa ennen kaikkea katsojien välisiä suhteita. Toista haaraa voitaisiin kutsua "tuplayhteisöllisyydeksi". Tällä tarkoitan sitä, että katsojia rohkaistaan paitsi osallistumaan ohjelmaan reaaliaikaisesti sosiaalisessa mediassa myös keräämään kokoon kasvokkaisia yhteisöjä. Esimerkiksi Docventures-ohjelman leffakerhot kannustavat tällaiseen osallistumiseen. Toisin kuin kaksi edellistä kolmas suunta ei niinkään pyri vahvistamaan katsojien välistä yhteisöllisyyttä, vaan se liittyy pikemminkin katsojien ja tuottajan väliseen vuorovaikutukseen. Tähän suuntaan Yle on viimeaikaisissa urheilulähetyksissään liikkunut rohkaistessaan katsojia lähettämään studioon Whatsappilla kysymyksiä, joihin asiantuntijat ovat reaaliaikaisessa lähetyksessä vastanneet.

Tutkimukseni perusteella live-tviittaamisen viehätys perustuu sekä vuorovaikutukseen että julkisuuteen. Toisin sanoen vuorovaikutus muiden osallistujien kanssa on yhtä oleellista kuin se, että tviittaaja voi ilmaista itseään julkisesti. Nämä kaksi perustavaa ominaisuutta kietoutuvat tavallisesti erottamattomasti toisiinsa. Onkin usein mahdoton sanoa, motivoiko tviittaamiseen ensisijaisesti vuorovaikutus sen yhteisön kanssa, joka ymmärtää tviittiin sisältyvät viittauskohteet, vai pikemmin luova itseilmaisu. Olennaista on kuitenkin se, että ihmiset haluavat syystä tai toisesta jättää jälkiä katsomiskokemuksestaan. Uskallankin väittää, että tästä syystä sosiaalisen me- 
dian kaltaiset palvelut tulevat jatkossa säilymään ja kenties vahvistumaan entisestään osana perinteisen median kulutusta.

\section{Lähteet}

Atifi, Hassan - Marcoccia, Michel 2017: Exploring the role of viewers' tweets in French TV political programs: Social TV as a new agora? - Discourse, Context \& Media 19 s. 31-38. https://doi.org/10.1016/j.dcm.2017.03.002.

Chovanec, Jan - Dynel, Marta 2015: Researching interactional forms and participant structures in public and social media. - Marta Dynel \& Jan Chovanec (toim.), Participation in public and social media interactions s. 1-23. Amsterdam: John Benjamins. https:// doi.org/10.1075/pbns.256.01cho.

COUldry, Nick 2003: Media rituals. A critical approach. London: Routledge.

Deller, Ruth 2011: Twittering on. Audience research and participation using Twitter. - Participations. Journal of Audience and Reception Studies 8 s. 216-245.

Enli, Gunn - Syvertsen, Trine 2016: The end of television - Again! How TV is still influenced by cultural factors in the age of digital intermediaries. - Media \& Communication 4 s. 142-153. http://dx.doi.org/10.17645/mac.v4i3.547.

Fairclough, Norman 1995: Miten media puhuu. Suomentaneet Virpi Blom \& Kaarina Hazard. Tampere: Vastapaino.

Giles, David - Stommel, Wyke - Paulus, Trena - Lester, Jessica - Reed, DarREN 2015: Microanalysis of Online Data. The methodological development of "digital CA". - Discourse, Context and Media 7 s. 45-51. https://doi.org/10.1016/j.dcm.2014.12.002.

HARrington, StePhen 2014: Tweeting about the telly. Live TV, audiences, and social media. - Katrin Weller, Axel Bruns, Jean Burgess, Merja Mahrt \& Cornelius Puschmann (toim.), Twitter and Society s. 237-247. New York: Peter Lang. https://nbn-resolving.org/ urn:nbn:de:0168-ssoar-47764-2.

Highfield, Tim 2014: Following the yellow jersey. Tweeting the Tour de France. - Katrin Weller, Axel Bruns, Jean Burgess, Merja Mahrt \& Cornelius Puschmann (toim.), Twitter and Society s. 249-262. New York: Peter Lang. https://nbn-resolving.org/urn:nbn:de:0168ssoar-47764-2.

Landert, Daniela 2017: Participation as user involvement. - C. Hoffmann \& W. Bublitz (toim.), Pragmatics of social media s. 31-59. Berlin: De Gruyter Mouton. https://doi. org/10.1515/9783110431070-002.

Meier, Florian - Elsweiler, David - Wilson, Max 2014: More than liking and bookmarking? Towards understanding Twitter favouriting behaviour. - Proceedings of the eighth international AAAI conference on weblogs and social media. Michigan, USA, June 1-4, 2014.

PAge, Ruth 2012: The linguistics of self-branding and micro-celebrity in Twitter. The role of hashtags. - Discourse \& Communication 6 s. 181-201. https://doi. org/10.1177/1750481312437441.

Selva, Donatella 2016. Social television. Audience and political engagement. Television \& New Media 17 s. 159-173. https://doi.org/10.1177/1527476415616192.

Thornborrow, JoANnA 2015: The discourse of public participation media. From talk show to Twitter. London: Routledge.

Yle 2014. Saksan murskavoitto Brasiliasta löi Twitter-ennätyksiä - kaikkien aikojen keskustelluin peli. https://yle.fi/uutiset/3-7345932 (4.12.2019). 
Elina Salomaa: Television ja Twitterin risteyksessä: Sosiaalinen televisio vuorovaikutuksen ja mediatapahtumaan osallistumisen välineenä. JYU Dissertations 140. Jyväskylä: Jyväskylän yliopisto 2019. Kirja on luettavissa osoitteessa http://urn.fi/ URN:ISBN:978-951-39-7869-3.

Kirjoittajan yhteystiedot:

etunimi.h.sukunimi@jyu.fi 